DOI: 10.31393/reports-vnmedical-2021-25(3)-19

UDC: $616.517-055.1: 159.923$

\title{
LEADING TYPOLOGICAL CHARACTERISTICS OF TEMPERAMENT AND PSYCHODYNAMIC PERSONALITY TRAITS IN MEN WITH PSORIASIS WITHOUT AND TAKING INTO ACCOUNT THE SOMATOTYPE
}

\author{
Obadeh Bassam Abdel-Rahman Al-Qaraleh
}

National Pirogov Memorial Medical University, Vinnytsya (Pyrogov street 56, Vinnytsya, Ukraine, 21018)

Responsible for correspondence: e-mail:dr.obadabassam@gmail.com

Received: July, 16, 2021; Accepted: August, 20, 2021

Annotation. One of the most important problems of modern dermatology is the individualization of programs for diagnosis, treatment and prevention of skin diseases. The success of its solution largely depends on how fully, systematically will be described and somatic and mental components of the patient's personality, taking into account the full range of biological and mental factors that affect his health. The aim of the study was to establish the features of the leading typological characteristics of temperament and psychodynamic personality traits between healthy and psoriatic men without taking into account somatotype and representatives of mesomorphic and endo-mesomorphic somatotypes. Men aged 22 to 35 years, patients with psoriasis ( $n=100$, including 32 with mild and 68 with severe) conducted an anthropometric examination according to V. V. Bunak Somatotype was calculated according to the mathematical scheme of J. Carter and B. Heath. The PASI (Psoriasis Area and Severity Index) was used to clinically assess the severity and area of psoriatic lesions. The control group consisted of anthropometric data of 82 practically healthy men of the same age group from the data bank of the research center of National Pirogov Memorial Medical University, Vinnytsya. Evaluation of the leading typological characteristics of temperament was determined by G. Eysenck, psychodynamic personality traits - by C. D. Spielberger in the modification of $Y$. L. Khanin Statistical processing was performed in the license package "Statistica 5.5" using non-parametric evaluation methods. When comparing the studied indicators between groups with different disease course, significantly higher and tendencies to higher values of the percentage were found: persons with potential introversion among patients in general (19.12\%) and endo-mesomorphs (22.22 $\%)$ with severe course compared to healthy subjects without taking into account the somatotype (8.54\%) and the control group of a similar somatotype (0\%); persons with a low level of neuroticism among patients in general (50.00\%), mesomorphs (46.43\%) and endo-mesomorphs $(75.00 \%)$ with mild psoriasis compared with patients without somatotype, mesomorphs and endo-mesomorphs with severe dermatosis (19.12\%., $18.18 \%$ and $11.11 \%)$; persons with an average level of neuroticism among patients in general (22.06 $\%)$ and mesomorphs (20.00\%) with severe psoriasis compared with patients without somatotype and mesomorphs with mild dermatosis $(3.13 \%, 3.57 \%)$; persons who answered insincerely, among patients with mild psoriasis $(87.50 \%)$ compared with patients with severe psoriasis (66.18\%); persons with a low level of situational anxiety among patients in general (12.50 \%) and mesomorphs (14.29\%) with a mild course of psoriasis compared with patients without somatotype and mesomorphs with a severe course of dermatosis (2.94 $\%$ and $3.04 \%)$; persons with a low level of situational anxiety among patients in general (21.88 \%) and mesomorphs (17.86 \%) with a mild course of psoriasis compared with patients without somatotype and mesomorphs with a severe course of dermatosis ( $8.82 \%$ and $5.45 \%)$. When comparing the studied indicators between groups with different body type, significantly higher and tendencies to higher values of the percentage of people with an average level of situational anxiety among endo-mesomorphs with mild and severe psoriasis (100\% in both cases) compared with mesomorphs. the corresponding severity of the disease (63.64\% and $46.43 \%)$; persons with a high level of situational anxiety among mesomorphs with severe psoriasis (30.91\%), compared with endo-mesomorphs with a corresponding severity of the disease (0\%); persons with a low level of personal anxiety among endo-mesomorphs suffering from severe psoriasis (22.22 \%), compared with mesomorphs suffering from dermatosis of similar severity (5.45 \%); persons with a low level of personal anxiety among healthy endo-mesomorphs (46.15\%) compared with healthy mesomorphs (12.82\%); persons with an average level of personal anxiety among healthy mesomorphs (71.79\%) compared with healthy endo-mesomorphs (30.47\%). Thus, our study, conducted using a constitutional approach, allowed us to describe systemic portraits of patients with psoriasis, including the strengths and weaknesses of their morphological and mental organization, necessary to justify differentiated approaches to planning health and prevention measures.

Keywords: men, psoriasis, extraversion, introversion, neuroticism, situational and personal anxiety.

\section{Introduction}

One of the biggest public health challenges is the widespread use of skin pathologies, the etiology and etiotropic therapy of which are unknown. A special place among dermatological diseases is psoriasis, a chronic autoimmune skin disease that manifests itself in the form of red papules that rise above the level of intact skin, cause itching and merge to form plaques.

And although psoriasis is not an infectious disease and is not contagious, its prevalence is impressive. In total, about 125 million people in the world suffer from this disease. Its prevalence in different countries is quite heterogeneous. Thus, if in the United States its prevalence is $0.91 \%$ (the same low rates are observed in most countries in Africa and Asia), in Norway the prevalence is rising sharply and is already $8.5 \%$ (the same high rates were found in other Scandinavian countries) [12].

The lack of a reliable method of treatment, the chronic course and the high prevalence of psoriasis cause a 
correspondingly heavy economic burden for the population and the economy as a whole. An analysis of 22 studies found that patients in the United States had direct costs of treating psoriasis ranging from $\$ 51.7$ billion to $\$ 63.2$ billion, and indirect costs from $\$ 23.9$ billion to $\$ 35.4$ billion. Thus, for the life of one patient spends $\$ 11,498$ on the treatment of this disease, and the total cost of psoriasis treatment in the United States in 2013 amounted to 112 billion dollars [5].

In addition, you should pay attention to the emotional component of the lives of patients with psoriasis. These individuals have an increased risk of concomitant mental illness and suicidal ideation compared to patients with other dermatological diseases (and even melanoma) [18].

Thus, there is an urgent need for in-depth study of personality traits in patients with psoriasis, using simple research methods that would identify risk groups even in mass screening examinations. Anthropometric research is such a method of research that would unite both mental and somatic nature of a person [2].

The aim of the study was to establish the features of the leading typological characteristics of temperament and psychodynamic personality traits between healthy and psoriatic men without taking into account somatotype and representatives of mesomorphic and endo-mesomorphic somatotypes.

\section{Materials and methods}

Men aged 22 to 35 years, patients with psoriasis $(n=100$, including 32 with mild and 68 with severe course) at the Department of Dermatology and Venereal Diseases with a course of postgraduate education National Pirogov Memorial Medical University, Vinnytsya and Military Medical clinical center of the Central region, conducted an anthropometric survey on V. V. Bunak [6]. The somatotype was calculated according to the mathematical scheme of J. Carter and B. Heath [7].

The PASI (Psoriasis Area and Severity Index) was used to clinically assess the severity and area of psoriatic lesions [11]. The intensity of erythema, infiltration and peeling was determined by the scoring system: 0 points - no symptom, 1 - mild, 2 - moderate, 3 - severe, 4 - very severe. The following formula was used to calculate the PASI index for each body area: the coefficient of the anatomical area of the body (for the head -0.1 , the upper extremities -0.2 , the torso -0.3 , the lower extremities - 0.4) x (erythema severity + infiltration severity + severity of peeling) $x$ the area of skin lesions of the corresponding anatomical region of the body. Assessment of the severity of psoriasis was performed on the total PASI index (the sum of the obtained indices for each body area): mild - PASI value <10; medium degree PASI values from 10 to 20; severe - PASI value> 20 [3]. When divided into somatotypes, it was found that of the 32 patients with mild psoriasis, 28 belong to the mesomorphic somatotype and 4 - to the endo-mesomorphic somatotype; and of the 68 patients with severe psoriasis, 55 belong to the mesomorphic somatotype, 9 to the endo-mesomorphic somatotype, and 2 to the ectomorphic and ectomesomorphic somatotype.

The control group consisted of anthropometric data of 82 practically healthy men of the same age group from the data bank of the research center National Pirogov Memorial Medical University, Vinnytsya. Among practically healthy men, 39 had a mesomorphic somatotype and 13 had an endo-mesomorphic somatotype.

The study of individual-personal properties of the organism was carried out with the help of personality questionnaires [9, 17, 19].

The evaluation of the leading typological characteristics of temperament according to Eysenck G. included the definition (score): the indicator on the scale of extraversionintroversion (AZ_E), the indicator on the scale of neuroticism $\left(A Z \_N\right)$ and the indicator on the scale of insincerity $\left(A Z \_L\right)$.

Determination of psychodynamic personality traits by C. D. Spielberger in the modification of Y. L. Khanin included the definition (score): situational (reactive) anxiety (SP_ST) and personal anxiety (SP_LT).

Statistical processing was performed in the license package "Statistica 5.5" using non-parametric evaluation methods. The reliability of the difference between the values between the independent quantitative values was determined using the Mann-Whitney U-test.

\section{Results. Discussion}

The influence of psoriasis on psychoemotional status is generally recognized $[1,10,15]$. The chronic nature of dermatosis, the severity of the course with frequent recurrences lead to a violation of the usual style of behavior, insomnia, disharmony with the outside world, the emergence of neurotic reactions, anxiety and depression. Patients with psoriasis differ from healthy peers in communication difficulties, spontaneity, emotional incontinence, insecurity and hypersensitivity $[4,8]$. According to K. Janowski et al. [13] anxiety disorders, found in $95 \%$ of patients with psoriasis, predominate in patients with more severe course.

In the study of the level of extroversion in patients with this dermatosis in children, its reduction was determined as the severity of the disease [16, 21]. The authors characterize patients in comparison with the control group as more closed, shy, who seek to protect their inner world from others. Indicate a high rate of emotional instability (neuroticism), which increases with increasing severity of the disease.

At the same time, J. Zeljko-Penaviж [23] notes that in patients with psoriasis, the indicators that characterize the orientation of the personality (extraversion) did not differ from healthy subjects and corresponded to the normative indicators of their age group. It should be borne in mind that the author in the study analyzed only averages. Similarly, in our study, when comparing the average values of extroversion between healthy men and patients with mild 

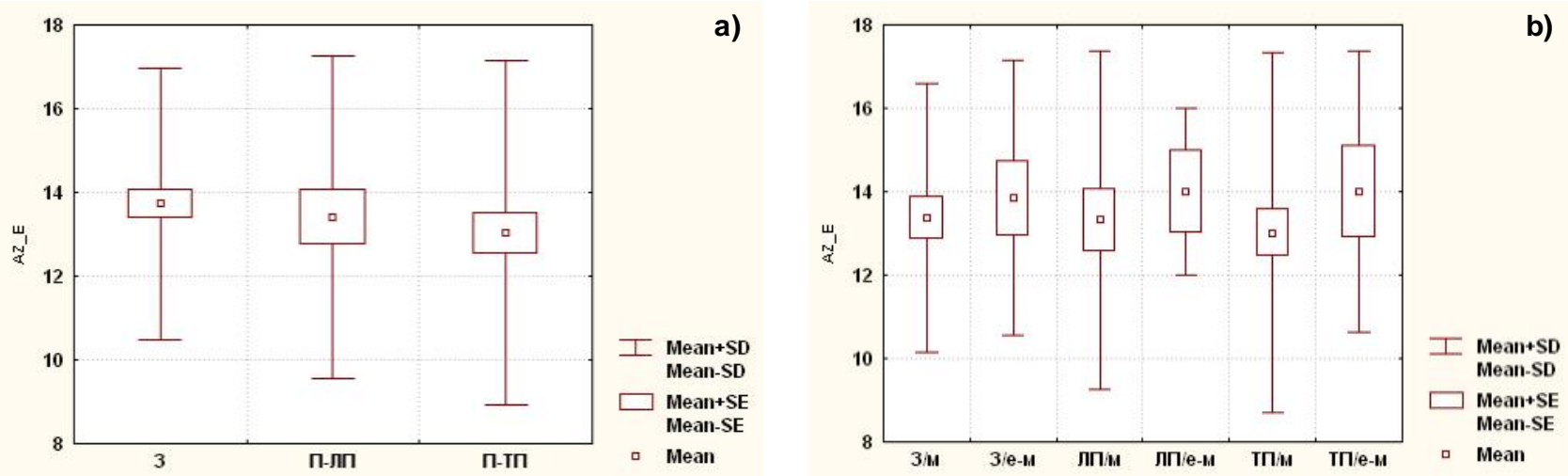

Fig. 1. The value of the extraversion-introversion scale according to Eysenck $(A Z E)$ in healthy and psoriasis men without somatotype (a) and in representatives of mesomorphic and endo-mesomorphic somatotypes (b) (points). Here and in the future, 3 - healthy men of the general group; П-ЛП - patients with mild psoriasis of the general group; П-ТП - patients with severe psoriasis of the general group; 3/M - healthy men of mesomorphic somatotype; 3/e-M - healthy men of endo-mesomorphic somatotype; ЛП/M - men with mesomorphic somatotype patients with mild psoriasis; ЛП/е-M - patients with mild psoriasis of endo-mesomorphic somatotype; ТП/M - patients with severe psoriasis of mesomorphic somatotype; TП/e-M - patients with severe psoriasis of endo-mesomorphic somatotype; Mean average value; Mean $\pm S E$ - average value \pm mean error; Mean $\pm S D$ - mean \pm standard deviation.
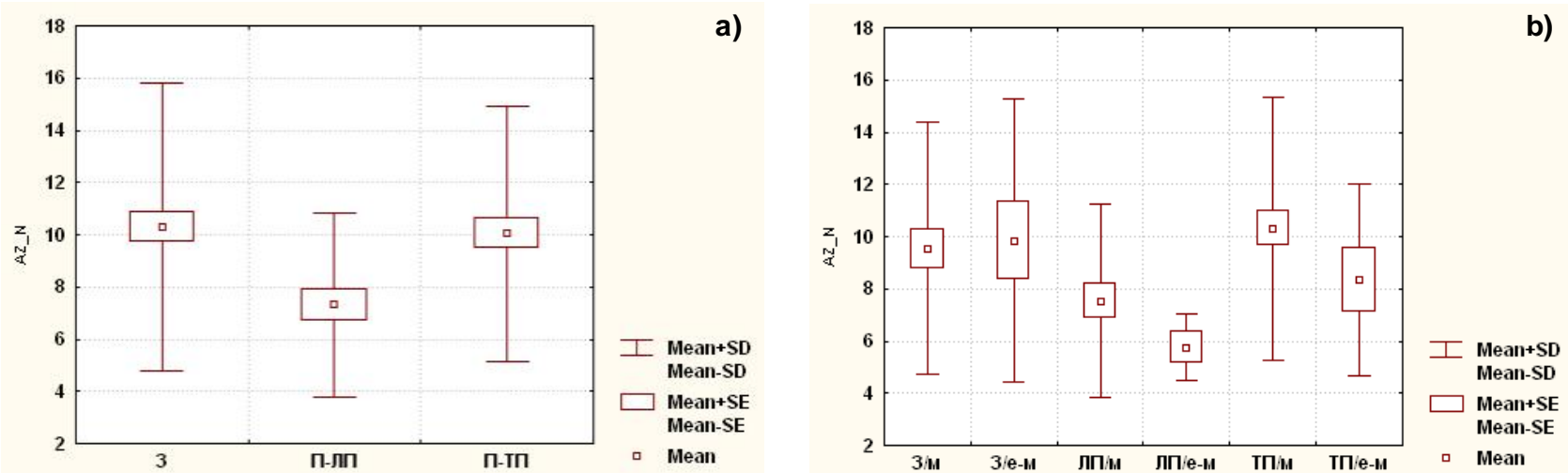

Fig. 2. The value of the Eysenck neuroticism score (AZ_N) in healthy and psoriatic men without taking into account somatotype (a) and in representatives of mesomorphic and endo-mesomorphic somatotypes (b) (points).

and/or severe psoriasis without and taking into account the somatotype, no significant differences or differences were found (Fig. 1).

The two-factor model of personality proposed by Eysenck allowed us to assess the orientation of the individual to the inner or outer world, as well as to identify the level of emotional tension during the determination of the percentage distribution by the level of the main indicators between the studied groups. The level of extraversion-introversion and neuroticism are genetically determined and their manifestation is purely individual. These properties of the personality structure significantly affect the course and prognosis of psoriasis.

The percentage of people with a predominance of introversion is usually higher compared to healthy people. Introverted patients are often so "immersed in the disease", "obsessed" with painful feelings, that they constantly think about their disease and its consequences. It was found that the percentage of people with potential introversion tends $(p=0.058)$ to higher values in patients with severe psoriasis $(19.12 \%)$ compared with healthy subjects (8.54
$\%)$. The percentage of persons with potential introversion tends $(p=0.089)$ to higher values in endo-mesomorphs with severe psoriasis $(22.22 \%)$, compared with healthy subjects of the same somatotype $(0 \%)$.

Patients with more severe dermatosis with and without taking into account somatotype have a higher level of neuroticism compared to similar groups compared with a milder course of the disease. The obtained results characterize the emotional instability of patients, and it is known that neuroticism, according to some data, is associated with indicators of lability of the nervous system.

It was found that the value of neuroticism was significantly $(p<0.01)$ lower in patients with mild psoriasis $(7.313 \pm 3.533$ points) compared with healthy men (10.29 \pm 5.52 points) and patients with severe $(10.04 \pm 4.89$ points) (Fig. 2$)$. The level of neuroticism was significantly $(p<0.05)$ lower in patients with mild psoriasis mesomorphs $(7.536 \pm 3.707$ points) and tends $(p=0.079)$ to lower values in patients' endo-mesomorphs (5.750 \pm 1.258 points) compared with healthy subjects of a similar somatotype $(9.539 \pm 4.839$ points; $9.846 \pm 5.414$ points). The value of this indicator is 

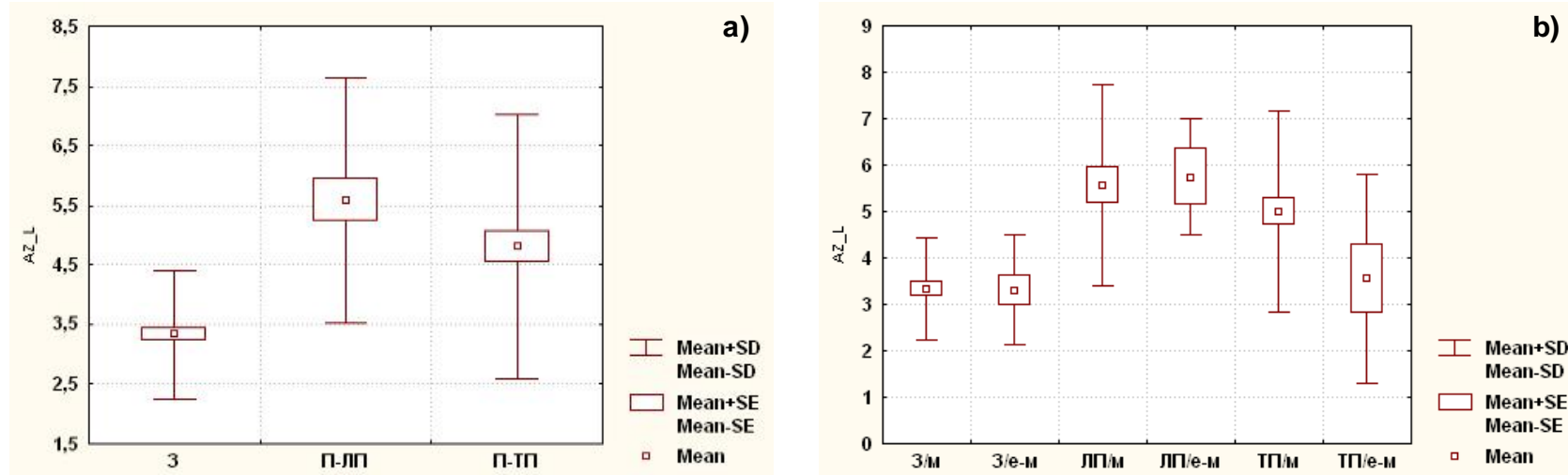

Fig. 3. The value of the Eysenck insincerity scale ( $A Z$ _ $L)$ in healthy and psoriatic men without taking into account somatotype (a) and in representatives of mesomorphic and endo-mesomorphic somatotypes (b) (points).

significantly $(p<0.01)$ greater in patients with mesomorphs with severe course $(10.31 \pm 5.04$ points) compared with patients of similar somatotype with mild course (7.536 \pm 3.707 points) (see Fig. 2).

The percentage of people with a low level of neuroticism was significantly $(p<0.001)$ higher in patients with mild psoriasis $(50.00 \%)$ compared with healthy subjects $(10.98$ $\%)$ and patients with severe $(19.12 \%)$ course. The percentage of people with low levels of neuroticism was significantly $(p<0.05)$ higher in mesomorphs $(46.43 \%)$ and endo-mesomorphs $(75.00 \%)$, patients with mild psoriasis compared with healthy subjects of similar somatotypes $(10.26 \%$ and $15.38 \%)$ and compared with patients with mesomorphs and endo-mesomorphs with severe dermatosis (18.18\% and $11.11 \%)$.

The percentage of people with an average level of neuroticism was significantly $(p<0.001)$ lower in patients with mild psoriasis $(3.13 \%)$ compared with healthy subjects $(17.07 \%)$ and patients with severe $(22.06 \%)$ course. The percentage of people with a medium level of neuroticism was significantly $(p<0.05)$ lower in mesomorphs with mild psoriasis $(3.57 \%)$ course, compared with healthy subjects of similar somatotype $(23.08 \%)$ and patients with mesomorphs with severe dermatosis $(20.00 \%)$.

The percentage of people with a potentially high level of neuroticism tends $(p=0.066)$ to lower values in patients with mild psoriasis $(3.13 \%)$ compared with healthy subjects (15.85\%).

It was found that the value of insincerity was significantly $(p<0.01)$ higher in patients with mild $(5.594 \pm 2.061$ points $)$ and severe dermatosis $(4.806 \pm 2.210$ points) compared with healthy subjects $(3.329 \pm 1.078$ points) (Fig. 3$)$.

The value of insincerity tends to be higher $(p=0.079)$ values in patients with severe mesomorphs $(5.000 \pm 2.181$ points) compared with patients with endo-mesomorphs with similar severity of psoriasis (3.556 \pm 2.242 points). The rate of insincerity is significantly $(p<0.001)$ higher in patients' mesomorphs with mild $(5.571 \pm 2.168$ points $)$ and severe dermatosis $(5.000 \pm 2.181$ points) compared with healthy subjects of a similar somatotype (3.333 \pm 1.108 points). This indicator is significantly $(p<0.05)$ higher in patients with mild course endo-mesomorphs $(5.750 \pm 1.258$ points) compared to healthy subjects of a similar somatotype (3.308 \pm 1.182 points) (see Fig. 3).

The percentage of people who answered insincerely was significantly $(p<0.05)$ higher in patients with mild psoriasis $(87.50 \%)$ compared with healthy subjects $(64.63$ $\%)$ and patients with severe $(66.18 \%)$ course.

According to some authors, in increasing the level of personal and situational anxiety play an important role factors such as discomfort in the affected area of the skin of the body, limbs and scalp, joint dysfunction (common and complicated form), deterioration and loss of social status. contacts. A significant correlation has been established between the positive dynamics of the disease and a decrease in the level of neuroticism and anxiety [14, 22].

In a study of Spielberg's anxiety indicators, C. Remröd [21] found significantly higher values in adolescents with psoriasis than in healthy people. In addition, the rates of personal anxiety in patients were significantly higher than the rates of reactive anxiety. In healthy adolescents, the rate of reactive anxiety was slightly higher than in patients with peers.

Analysis of the data obtained by us in the survey of patients on the scale of self-assessment of anxiety Spielberg-Khanin, revealed the presence of patients with psoriasis of moderate reactive and personal anxiety.

It was found that the value of situational anxiety tends to higher $(p=0.097)$ values in patients with severe disease (41.93 \pm 8.14 points) compared with patients with mild psoriasis (38.75 \pm 7.65 points) (Fig. 4).

The rate of situational anxiety was significantly $(p<0.01)$ higher in patients' mesomorphs with a mild course of dermatosis (39.18 \pm 8.06 points) compared with healthy subjects of a similar somatotype (38.13 \pm 6.40 points) (see Fig. 4).

Obviously, the decrease in the level of reactive anxiety in patients with psoriasis compared to the level in healthy people can be explained by a positive response to 

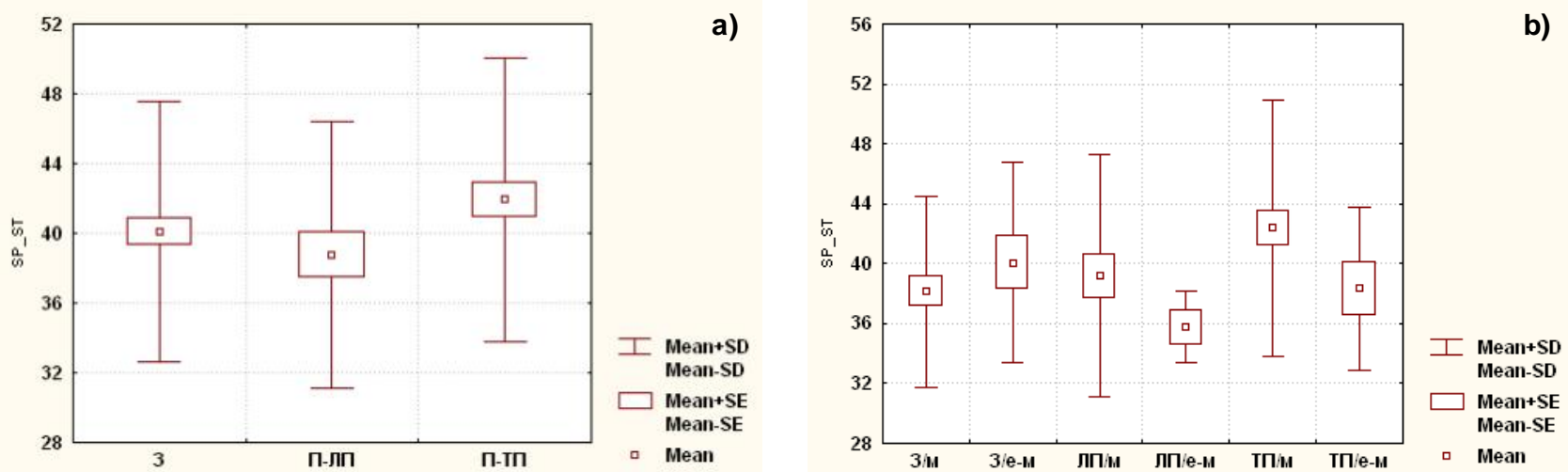

Fig. 4. The value of the indicator of situational (reactive) anxiety according to Spielberger (SP_ST) in healthy and psoriatic men without taking into account somatotype (a) and in representatives of mesomorphic and endo-mesomorphic somatotypes (b) (points).
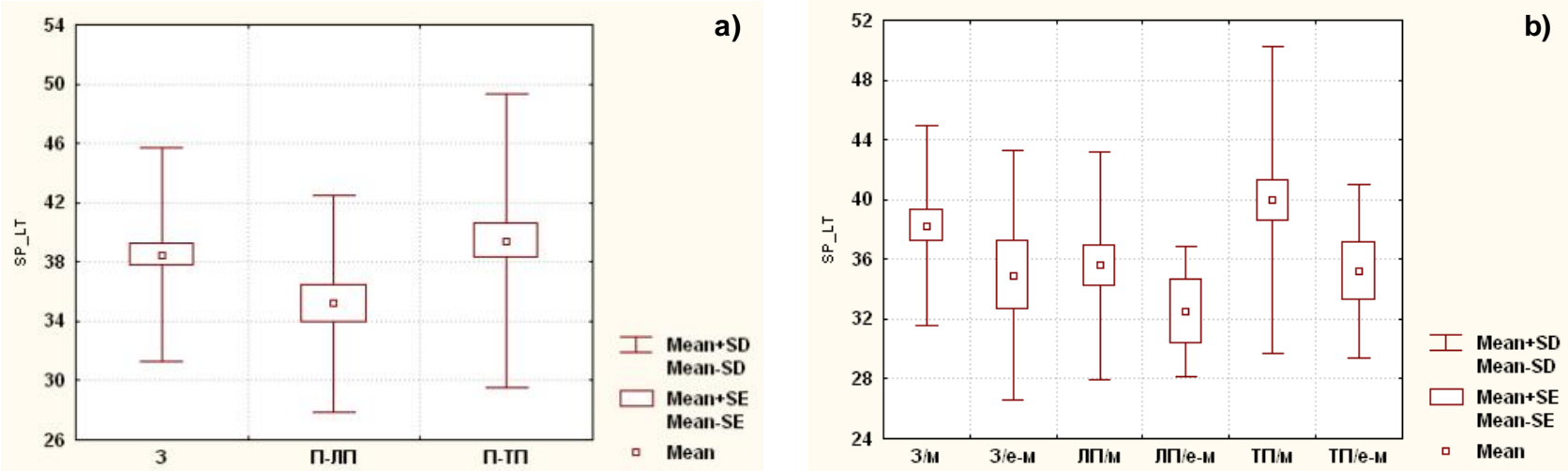

Fig. 5. The value of Spielberger's personal anxiety index (SP_LT) in healthy and psoriatic men without taking into account somatotype (a) and in representatives of mesomorphic and endo-mesomorphic somatotypes (b) (points).

treatment, the possibility of improving the somatic condition [20].

The percentage of people with a low level of situational anxiety tends $(p=0.063)$ to higher values in patients with mild psoriasis $(12.50 \%)$ compared with patients with severe psoriasis $(2.94 \%)$. The percentage of people with an average level of situational anxiety was significantly $(p<0.05)$ lower in patients with mild psoriasis $(55.13 \%)$ compared with the control group (73.17\%).

The percentage of people with a low level of situational anxiety tends $(p=0.080)$ to higher values in mesomorphs with mild psoriasis (14.29\%), compared with patients of similar somatotype with severe disease $(3.04 \%)$ course. The percentage of people with an average level of situational anxiety is significantly $(p<0.05)$ higher in endomesomorphs with severe psoriasis $(100 \%)$, and tends $(p=0.054)$ to higher values in endo-mesomorphs with mild dermatosis $(100 \%)$ compared with mesomorphs with the corresponding severity of the disease $(63.64 \%$ and 46.43 $\%)$. The percentage of persons with an average level of situational anxiety was significantly $(p<0.05)$ lower in mesomorphs with mild psoriasis $(46.43 \%)$ compared with the control group of a similar somatotype (79.92\%). High levels of situational anxiety are detected significantly more often in mesomorphs with severe psoriasis (30.91\%) compared with endo-mesomorphs with a corresponding severity of the disease $(0 \%)$.

It was found that the value of the indicator of personal anxiety was significantly $(\mathrm{p}<0.05)$ lower in patients with mild disease (35.19 \pm 7.31 points) compared with patients with severe psoriasis (39.42 \pm 9.94 points) and with healthy subjects (38.47 \pm 7.21 points) (Fig. 5)

The indicator of personal anxiety tends $(p=0.091)$ to higher values in healthy mesomorphs (38.26 \pm 6.65 points) compared to healthy endo-mesomorphs (34.92 \pm 8.36 points). This indicator is significantly $(p<0.05)$ lower in patients with mesomorphs with a mild course of dermatosis (35.57 \pm 7.61 points) compared to healthy subjects of a similar somatotype (38.26 \pm 6.65 points) and tends $(p=0.067)$ to lower values compared with patients with severe course $(39.96 \pm 10.23$ points) (see Fig. 5).

The percentage of people with a low level of personal anxiety tends $(p=0.073)$ to higher values in patients with mild psoriasis $(21.88 \%)$ compared with patients with severe $(8.82 \%)$ course.

The percentage of people with low levels of personal anxiety tends $(p=0.074)$ to higher values in mesomorphs with mild psoriasis (17.86\%) course, compared with patients of similar somatotype with severe disease $(5.45$ $\%)$. The percentage of people with a low level of personal 
anxiety tends $(p=0.087)$ to higher values in endomesomorphs with severe psoriasis (22.22\%), compared with mesomorphs with dermatosis of similar severity $(5.45$ $\%)$. The percentage of people with a low level of personal anxiety was significantly $(p<0.05)$ higher in healthy endomesomorphs $(46.15 \%)$ compared to healthy mesomorphs (12.82\%).

The percentage of people with an average level of personal anxiety was significantly $(p<0.05)$ lower in healthy endo-mesomorphs $(30.47 \%)$ compared to healthy mesomorphs $(71.79 \%)$. The average level of situational anxiety is determined significantly $(p<0.05)$ more often in endo-mesomorphs with severe psoriasis $(77.78 \%)$, compared with healthy endo-mesomorphs (30.77\%).

Thus, when comparing the studied indicators between groups with different course of the disease, found significantly higher and tendencies to higher values of the percentage:

- persons with potential introversion among patients in general $(19.12 \%)$ and endo-mesomorphs (22.22 \%) with severe course compared with healthy subjects without taking into account somatotype (8.54\%) and the control group of a similar somatotype $(0 \%)$;

- persons with a low level of neuroticism among patients in general $(50.00 \%)$, mesomorphs (46.43\%) and endomesomorphs $(75.00 \%)$ with mild psoriasis compared with patients without taking into account somatotype, mesomorphs and endo-mesomorphs with severe course dermatosis (19.12\%, $18.18 \%$ and $11.11 \%$ );

- persons with an average level of neuroticism among patients in general $(22.06 \%)$ and mesomorphs (20.00\%) with severe psoriasis compared with patients without taking into account somatotype and mesomorphs with mild dermatosis $(3.13 \%, 3.57 \%)$;

- people who answered insincerely, among patients with mild psoriasis $(87.50 \%)$ compared with patients with severe psoriasis $(66.18 \%)$;

- persons with a low level of situational anxiety among patients in general (12.50\%) and mesomorphs (14.29\%) with mild psoriasis compared with patients without taking into account somatotype and mesomorphs with severe dermatosis $(2.94 \%$ and $3.04 \%)$;

- persons with a low level of situational anxiety among patients in general $(21.88 \%)$ and mesomorphs $(17.86 \%)$ with mild psoriasis compared with patients without taking into account somatotype and mesomorphs with severe dermatosis (8.82 \% and $5.45 \%$ ).

\section{References}

[1] Almeida, V., Taveira, S., Teixeira, M., Almeida, I., Rocha, J., \& Teixeira, A. (2017). Emotion regulation in patients with psoriasis: Correlates of disability, clinical dimensions, and psychopathology symptoms. International journal of behavioral medicine, 24(4), 563-570. doi: 10.1007/s12529016-9617-0

[2] Andriievskyi, I. I., Serebrennikova, O. A., Kyrychenko, I. M., Zhuchenko, I. I., \& Gunas, V. I. (2020). Correlations of body structure and size indicators with personality indicators of
When comparing the studied indicators between groups with different body type, found significantly higher and tendencies to higher values of the percentage:

- persons with an average level of situational anxiety among endo-mesomorphs with mild and severe psoriasis (100\% in both cases) compared with mesomorphs with the corresponding severity of the disease $(63.64 \%$ and $46.43 \%)$;

- persons with a high level of situational anxiety among mesomorphs suffering from severe psoriasis (30.91\%), compared with endo-mesomorphs with a corresponding severity of the disease (0\%);

- persons with a low level of personal anxiety among endo-mesomorphs suffering from severe psoriasis $(22.22$ $\%$ ), compared with mesomorphs suffering from dermatosis of similar severity $(5.45 \%)$;

- persons with a low level of personal anxiety among healthy endo-mesomorphs $(46.15 \%)$ compared with healthy mesomorphs (12.82 \%);

- persons with an average level of personal anxiety among healthy mesomorphs $(71.79 \%)$ compared with healthy endo-mesomorphs (30.47\%).

Thus, one of the most important problems of modern dermatology is the individualization of programs for diagnosis, treatment and prevention of skin diseases. The success of its solution largely depends on how fully, systematically will be described and somatic and mental components of the patient's personality, taking into account the full range of biological and mental factors that affect his health.

\section{Conclusions and prospects for further development}

1. It was found that in subjects with taking into account and without taking into account somatotype, the degree of manifestation of extraversion is lower, and neuroticism, situational and personal anxiety - greater with respect to the course of psoriasis.

2. Higher levels of situational and personal anxiety were found in healthy individuals and in patients with different dermatosis course of mesomorphic somatotype compared to endo-mesomorphs of similar comparison groups.

Further research is planned to evaluate the features of indicators of severity and features of accentuated personality traits, as well as indicators of the level of subjective control in men with psoriasis without and taking into account the somatotype.

practically healthy women with mesomorphic somatotype. Biomedical and Biosocial Anthropology, 39, 35-44. doi: 10.31393/bba39-2020-06

[3] Augustin, M., Krüger, K., Radtke, M. A., Schwippl, I., \& Reich, K. (2008). Disease severity, quality of life and health care in plaque-type psoriasis: a multicenter cross-sectional study in Germany. Dermatology, 216(4), 366-372. doi: 10.1159/ 000119415

[4] Bewley, A., Burrage, D. M., Ersser, S. J., Hansen, M., \& Ward, C. 
(2014). Identifying individual psychosocial and adherence support needs in patients with psoriasis: a multinational two stage qualitative and quantitative study. Journal of the European academy of dermatology and venereology, 28(6), 763-770. doi: 10.1111/jdv.12174

[5] Brezinski, E. A., Dhillon, J. S., \& Armstrong, A. W. (2015). Economic burden of psoriasis in the United States: a systematic review. JAMA dermatology, 151(6), 651-658. doi: 10.1001/ jamadermatol.2014.3593

[6] Bunak, V. V. (1941). Антропометрия [Anthropometry]. M.: Наркомпрос РСФСР - M.: People's Commissariat of the RSFSR

[7] Carter, J. (2003). The Heath-Carter antropometric somatotype. Instruction manual. Department of Exercise and Nutritional Sciences San Diego State University. CA. U.S.A.

[8] Connor, C. J., Liu, V., \& Fiedorowicz, J. G. (2015). Exploring the physiological link between psoriasis and mood disorders. Dermatology research and practice, 2015, 409637. doi: $10.1155 / 2015 / 409637$

[9] Eliseev, О. Р. (2010). Практикум по психологии [Workshop on psychology]. СПб: Питер. - St. Petersburg: Peter.

[10] Finzi, A., Colombo, D., Caputo, A., Andreassi, L., Chimenti, S., Vena, G., ... \& PSYCHAE Study Group. (2007). Psychological distress and coping strategies in patients with psoriasis: the PSYCHAE Study. Journal of the European Academy of Dermatology and Venereology, 21(9), 1161-1169. doi: 10.1111/ j.1468-3083.2007.02079.x

[11] Fredriksson, T., \& Pettersson, U. (1978). Severe psoriasis oral therapy with a new retinoid. Dermatology, 157(4), 238244. doi: $10.1159 / 000250839$

[12] Griffiths, C. E. M., van der Walt, J. M., Ashcroft, D. M., Flohr, C. Naldi, L., Nijsten, T., \& Augustin, M. (2017). The Global State of Psoriasis Disease Epidemiology: A Workshop Report. The British journal of dermatology, 177(1), e4-e7. doi: 10.1111/ bjd. 15610

[13] Janowski, K., Steuden, S., \& Bogaczewicz, J. (2014). Clinical and psychological characteristics of patients with psoriasis reporting various frequencies of pruritus. International journal of dermatology, 53(7), 820-829. doi: 10.1111/ijd.12074

[14] Jaworecka, K., Kwiatkowska, D., Marek, L., Tamer, F., Stefaniak, A., Szczegielniak, M., ... \& Reich, A. (2021). Characteristics of Pruritus in Various Clinical Variants of Psoriasis: Results of the Multinational, Multicenter, CrossSectional Study. Life, 11(7), 623. doi: 10.3390/life11070623
[15] Lakuta, P., \& Przybyla-Basista, H. (2017). Toward a better understanding of social anxiety and depression in psoriasis patients: The role of determinants, mediators, and moderators. Journal of psychosomatic research, 94, 32-38. doi: 10.1016/ j.jpsychores.2017.01.007

[16] Merola, J. F., Qureshi, A., \& Husni, M. E. (2018). Underdiagnosed and undertreated psoriasis: Nuances of treating psoriasis affecting the scalp, face, intertriginous areas, genitals, hands, feet, and nails. Dermatologic therapy, 31(3), e12589. doi: 10.1111/dth. 12589

[17] Miroshnikov, S. A., Kravets, O. lu., Filippova, M. G., \& Chernov, R. V. (2006). Приложение к методическим материалам экспертной системы индивидуального сопровождения "Лонгитюд": описание дополнений расширенной версии "Лонгитюд+" [Appendix to the methodological materials of the expert system of individual support "Longitude". description of the additions to the extended version "Longituyd+"]. СПб. - St. Petersburg.

[18] Pompili, M., Innamorati, M., Trovarelli, S., Narcisi, A., Bellini, S., Orsini, D., ... \& Costanzo, A. (2016). Suicide risk and psychiatric comorbidity in patients with psoriasis. Journal of international medical research, 44(1_suppl), 61-66. doi: 10.1177/ 0300060515593253

[19] Raigorodskii, D. Ia. (2004). Практическая психодиагностика. Методики и тесты [Practical psychodiagnostics. Methods and tests]. Самара: Издательский дом "БахрахM" - Samara: Publishing House "Bahrah-M".

[20] Randa, H., Lomholt, J. J., Skov, L., \& Zachariae, R. (2018). Health-related quality of life in adolescents with psoriasis: an interview-based study. British Journal of Dermatology, 178(6), 1404-1411. doi: 10.1111/bjd.16326

[21] Remrod, C., Sjostrom, K., \& Svensson, E. (2013). Psychological differences between early-and late-onset psoriasis: a study of personality traits, anxiety and depression in psoriasis. British Journal of Dermatology, 169(2), 344-350. doi: 10.1111/ bjd.12371

[22] Wu, J. J., Feldman, S. R., Koo, J., \& Marangell, L. B. (2018). Epidemiology of mental health comorbidity in psoriasis. Journal of Dermatological Treatment, 29(5), 487-495. doi: 10.1080/ 09546634.2017 .1395800

[23] Zeljko-Penavic, J., Situm, M., Babic, D., \& Simic, D. (2013). Analysis of psychopathological traits in psoriatic patients. Psychiatr Danub, 25(Suppl 1), 56-59. PMID: 23806969

ОСОБЛИВОСТІ ПРОВІДНИХ ТИПОЛОГІЧНИХ ХАРАКТЕРИСТИК ТЕМПЕРАМЕНТУ ТА ПСИХОДИНАМІЧНИХ ОСОБЛИВОСТЕЙ ОСОБИСТОСТІ У ХВОРИХ НА ПСОРІАЗ ЧОЛОВІКІВ БЕЗ ТА 3 УРАХУВАННЯМ СОМАТОТИПУ

Обадех Бассам Абдель-Рахман Аль-Каралех

Анотація. Однією з найважливіших проблем сучасної дерматології є індивідуалізація програм діагностики, лікування та профрілактики захворювань шкіри. Успішність ї вирішення багато в чому залежить від того, наскільки повно, системно будуть описані і соматична, і психічна складові індивідуальності пацієнта з урахуванням всього комплексу біологічних та психічних фракторів, що впливають на його здоров'я. Мета дослідження - встановити особливості провідних типологічних характеристик темпераменту та психодинамічних особливостей особистості між здоровими та хворими на псоріаз чоловіками без урахування соматотипу та представниками мезоморфного й ендо-мезоморфного соматотипів. Чоловікам віком від 22 до 35 років, хворим на псоріаз ( $n=100$, серед яких 32 із легким перебігом і 68 із тяжким перебігом) проведено антропометричне обстеження за В. В. Бунаком. Соматотип розраховували за математичною схемою Ј. Саrter i B. Неаth. Для клінічної оцінки важкості перебігу і площі псоріатичних уражень використали індекс PASI (Psoriasis Area and Severity Index). Контрольну групу складали антропометричні дані 82 практично здорових чоловіків аналогічної вікової групи з банку даних науково-дослідного центру Вінницького національного медичного університету ім. М. І. Пирогова. Оцінку провідних типологічних характеристик темпераменту визначали за G. Eysenck, психодинамічних особливостей особистості - за C. D. Spielberger y модифікації Ю. Л. Ханіна. Cтатистична обробка проведена в ліцензійному пакеті "Statistica 5.5" із використанням непараметричних методів оцінки. При порівнянні досліджуваних показників між групами з різним перебігом захворювання, встановлено достовірно більші і тенденції до більших значень відсоткової частки: осіб з потенційною інтравертованістю серед хворих загалом (19,12 \%) і у ендо-мезоморфів (22,22 \%) з тяжким перебігом порівняно зі здоровими досліджуваними без урахування соматотипу (8,54 \%) і групою контролю аналогічного соматотипу (0 \%); осіб з низьким рівнем нейротизму серед хворих загалом (50,00 \%), у мезоморфів (46,43 \%) і ендо-мезоморфрів (75,00 \%) з легким перебігом псоріазу порівняно із хворими без урахування соматотипу, мезоморфрами і ендо-мезоморфами з тяжким перебігом дерма- 
тозу (19,12 \%, 18,18 \% і 11,11 \%); осіб з середнім рівнем нейротизму серед хворих загалом (22,06 \%) і у мезоморфрів (20,00 \%) з тяжким перебігом псоріазу порівняно із хворими без урахування соматотипу і мезоморфами з легким перебігом дерматозу (3,13 \%, 3,57 \%); осіб, які відповідали нещиро, серед хворих на псоріаз легкого перебігу (87,50 \%) порівняно із хворими $з$ тяжким перебігом (66,18 \%); осіб із низьким рівнем ситуативної тривожності серед хворих загалом (12,50 \%) i мезоморфрів $(14,29$ \%) з легким перебігом псоріазу порівняно із хворими без урахування соматотипу і мезоморфами з тяжким перебігом дерматозу (2,94 \% і 3,04 \%); осіб із низьким рівнем ситуативної тривожності серед хворих загалом (21,88 \%) i мезоморфів $(17,86$ \%) з легким перебігом псоріазу порівняно із хворими без урахування соматотипу і мезоморфами з тяжким перебігом дерматозу (8,82 \% і 5,45%). При порівнянні досліджуваних показників між групами з різним типом тілобудови, встановлено достовірно більші і тендениії до більших значень відсоткової частки осіб із середнім рівнем ситуативної тривожності серед ендо-мезоморфів, хворих на псоріаз легкого і тяжкого перебігу (100 \% в обох випадках) порівняно із мезоморфами 3 відповідною тяжкістю перебігу захворювання (63,64 \% і 46,43 \%); осіб з високим рівнем ситуативної тривожності серед мезоморфів, хворих на псоріаз тяжкого перебігу (30,91\%), порівняно із ендо-мезоморфрами з відповідною тяжкістю перебігу захворювання (0 \%); осіб із низьким рівнем особистісної тривожності серед ендо-мезоморфів, хворих на псоріаз тяжкого перебігу (22,22 \%), порівняно із мезоморфрами, хворими на дерматоз аналогічної тяжкості перебігу (5,45 \%); осіб із низьким рівнем особистісної тривожності серед здорових ендо-мезоморфрів (46,15 \%) порівняно із здоровими мезоморфрами (12,82 \%); осіб із середнім рівнем особистісної тривожності серед здорових мезоморфів (71,79 \%) порівняно із здоровими ендомезоморфами (30,47 \%). Отже, наше дослідження, проведене з використанням конституційного підходу, дозволило описати системні портрети хворих на псоріаз, що включають сильні та слабкі властивості їх морфологічної і психічної організації, необхідні для обгрунтування дифреренційованих підходів до планування здоров'язберігаючих і профрілактичних заходів.

Ключові слова: чоловіки, псоріаз, екстраверсія, інтроверсія, нейротизм, ситуативна і особистісна тривожність. 